\title{
Antioxidant and Antimicrobial Activity of Protein Hydrolysate Prepared From Tilapia Fish Waste by Enzymatic Treatment
}

\author{
A. Srikanya ${ }^{1}$, K. Dhanapal ${ }^{1 *}$, K. Sravani ${ }^{1}$, K. Madhavi ${ }^{2}$, \\ B. Yeshdas ${ }^{3}$ and G. Praveen Kumar ${ }^{1}$ \\ ${ }^{1}$ Department of Fish Processing Technology, ${ }^{2}$ Department of Aquatic Environment \\ Management, ${ }^{3}$ Department of Aquaculture, College of Fishery Science, Muthukur, Nellore \\ District, Andhra Pradesh, India \\ *Corresponding author
}

\section{A B S T R A C T}

The antioxidant and antimicrobial properties of fish protein hydrolysate (FPH) prepared

\section{Keywords}

Tilapia, Papain, FPH, Antioxidant, Antimicrobial

Article Info

Accepted: 20 September 2018 Available Online: 10 October 2018 from Tilapia waste was evaluated. The Protein hydrolysates was prepared from tilapia (Oreochromis niloticus) waste using papain enzyme under the optimum conditions viz., temperature of $50^{\circ} \mathrm{C}, \mathrm{pH}$ of $6.5, \mathrm{E} / \mathrm{S}$ ratio of $1 \%$ and 60 minutes time. The prepared proteinhydrolysate was evaluated for antioxidant and antimicrobial properties in vitro at different concentrations. The 2,2-diphenyl-1-picrylhydrazyl (DPPH) radical scavenging activity of FPH was highest at $100 \mathrm{mg} / \mathrm{L}(77.40 \%)$ and the maximum metal chelating activity of FPH was seen at 500mg/L (49.27\%). The DPPH radical scavenging activity and metal chelating activity showed concentration dependent activity. FPH showed ferric reducing activity at all concentrations and exhibited highest reducing power at $500 \mu \mathrm{g} / \mathrm{mL}$ $(2.18 \%)$. The antibacterial activity of FPH was seen at a concentration of 8 and $10 \mathrm{mg} / \mathrm{mL}$ FPH was potentially active against gram+ve bacteria viz., Staphylococcus aureus and Bacillus subtilis whereas, it showed smaller zones of inhibition against gram-ve Escherichia coli bacteria.

\section{Introduction}

Fish protein hydrolysates or peptides with antioxidant activities are released from fish proteins after enzymatic hydrolysis. These anti-oxidative peptides are inactive within the sequence of the precursor protein molecules but can be released after enzymatic hydrolysis. The anti-oxidative protein hydrolysates or peptides can be produced from fish protein sources by using various processes such as in vitro enzymatic hydrolysis, autolytic process using endogenous enzymes, microbial fermentation, and simulated gastric digestion (Bougatef et al., 2010). The antioxidant peptides possess some metal chelation or hydrogen/electron donating activity, which could allow them to interact with free radicals 
and terminate the radical chain reaction or prevent their formation (Ren et al., 2008). Therefore, the amino acid constituents and the sequence of the peptides are very important for their antioxidant activity. It has been shown that hydrophobic amino acids and one or more residues of Histidine, Proline, Methionine, Cysteine, Tyrosine, Tryptophan and Phenylalanine can enhance the activities of the antioxidant peptides. The presence of hydrophobic sequences in the peptides could interact with lipid molecules and could scavenge by donating protons to lipid derived radicals (Je et al., 2007).

Lipid oxidation leading to the development of undesirable off-flavors, odors, dark colors and potentially toxic reaction products is of great concern to the food industry and consumers (Lin and Liang, 2002). To prevent foods from undergoing such deterioration and provide protection, it is very important to inhibit lipid oxidation occurring in foodstuffs. Antioxidants are used to preserve food products by retarding discoloration and deterioration caused by oxidation. Antioxidant is defined as any substance that significantly delays or inhibits oxidation of a substance when present at low concentrations compared to that of an oxidizable substrate. Many synthetic antioxidants, such as butylatedhydroxytoluene butylatedhydroxyanisole (BHA), tertbutylhydroquinone (TBHQ), and propyl gallate (PG) are used as food additives to prevent deterioration. Although these synthetic antioxidants show stronger antioxidant activity than that of natural antioxidants ( $\alpha$-tocopherol and ascorbic acid) there is concern about their safety with regard to health (Ito et al., 1986). Therefore, the development of natural antioxidants as alternative to synthetic ones is of great interest among researchers. Vitamin $\mathrm{C}, \boldsymbol{\alpha}$-tocopherol and phenolic compounds, which are present naturally in vegetables, fruits and grains possess the ability to reduce oxidative damage associated with many diseases. Recently, the ability of phenolic substances including flavonoids and phenolic acid to act as antioxidants has been extensively investigated (Miraliakbari and Shahidi, 2008).

Antimicrobial peptides play key roles in native immunity by interacting directly with bacteria and killing them (Zhang et al., 2008). Researchers have reported that almost all fish antimicrobial peptides have antibacterial or bacteriostatic functions against several Gramnegative and Gram-positive strains ( $\mathrm{Su}, 2011)$. Antimicrobial peptides (AMPs) are known as importantcomponents of the innate immune system in a variety of organisms including both vertebrates and invertebrates (Arnesen and Gildberg, 2006). Hence, the objective of the present investigation was to prepare the protein hydrolysates from the tilapia fish waste using papain enzyme and evaluate the antioxidant and antimicrobial properties.

\section{Materials and Methods}

Raw material for preparation of fish protein hydrolysate (FPH)

The frame waste (FW) and head waste (HW) obtained from Tilapia fish (Oreochromis niloticus) were used as a raw material for preparation of fish protein hydrolysate (FPH). Fish waste was iced immediately after collection and transported in chill condition to laboratory. Immediately after arriving to the laboratory the fish wastes were washed thoroughly in chilled potable water. FW and HW were minced with meat mincer and packed in polythene bags and stored at $20 \pm 2^{\circ} \mathrm{C}$ until further use.

\section{Bacterial cultures}

Bacterial cultures, namely Staphylococcus aureus (NCIM 2079), Escherichia coli (NCIM 
2688), Bacillus subtilis (NCIM 2063) were used for the study.

Preparation of protein hydrolysates from Tilapia fish waste mince using papain

The protein hydrolysates were prepared by following the method as described by Srikanya et al., (2017) using the optimum conditions viz. temperature of $50^{\circ} \mathrm{C}, \mathrm{pH} 6.5 \pm$ 0.2 and hydrolysis time of $1 \mathrm{~h}$. Papain of $1 \%$ $\mathrm{E} / \mathrm{S}$ was used to achieve desired degree of hydrolysis.

The hydrolysis was terminated by keeping the reaction mixture in water bath. The slurry was filtered using Whatman No. 4 filter paper. The filtrate was dried in hot air oven at $80 \pm 2^{\circ} \mathrm{C}$ for $48-60 \mathrm{~h}$ to achieve a final moisture content of less than 5\%. The dried hydrolysates were stored in desiccated condition at ambient temperature $\left(25 \pm 2^{\circ} \mathrm{C}\right)$.

\section{Determination of antioxidant properties}

The DPPH radical quenching activity of FPH at various concentrations was determined according to the method as described by Yen and $\mathrm{Wu}(1999)$.

The ferric reducing antioxidant power of FPH was measured to reduce ferric ions to ferrous ions as determined at different concentrations by the method of Oyaizu (1986).

The chelating activity of FPH at different concentration was measured by the method of Boyer and Mccleary, 1987 and was compared with standard metal chelator EDTA at 1mM.

Determination of antimicrobial activity of fish protein hydrolysate (FPH)

The antibacterial test for FPH was performed by the well diffusion method (Bauer et al., 1966; Nair and Chanda, 2005).

\section{Statistical analysis}

The results were expressed as mean \pm Standard Deviation (SD). The correlation coefficients between the parameters were carried out using the same software. The Statistical Package for Social Sciences [SPSS 20 and IBM 2010] statistical package was used for analysis of the experimental results. Sufficient number of samples was carried out for each analysis.

\section{Results and Discussion}

\section{Proximate composition of FPH}

The results of proximate composition of FPH prepared from Tilapia waste are presented in Table 1. From the results it was observed that protein was the major component in proximate composition of FPH which constituted to $82.19 \%$ whereas the values of ash, moisture and fat were $11.06 \%, \quad 5.04 \%$ and $0.58 \%$ respectively. Protein content of FPH prepared from tilapia wastes was near to the values obtained from Tilapia meat hydrolysate (Foh et al., 2011), and catfish frame (Amiza et al., 2011). High protein content of FPH demonstrates its potential use as protein supplements for human nutrition. In the present study, it was observed that the lipid content of FPH was 5.04\% and such a lower fat content of FPH might be due to the removal of the fat layer after hydrolysis. Some authors have reported a lipid content below 5\% (Ovissipour et al., 2009, Bhaskar et al., 2008) whereas few authors have reported that the fat content was above 5\% level for FPH (Chalamaiah et al., 2010; Souissi et al., 2007).

The ash content of fish protein hydrolysates from tilapia was observed to be $11.06 \%$. Some authors have reported the ash content of fish protein hydrolysatein the range of $0.45-27 \%$ of total composition (Benjakul and Morrissey, 1997; Bhaskar et al., 2008). The high ash 
content of FPH in this study might be due to the addition of sodium phosphate buffer during enzymatic processing (Benjakul and Morrissey, 1997; See et al., 2011). Most studies have demonstrated that the protein hydrolysates from various fishes contain moisture <10\% (Wasswa et al., 2007; Bhaskar et al., 2008; Chalamaiah et al., 2010). In the present study, the FPH moisture content was $5.04 \pm 0.03 \%$ which is in agreement with Bueno-Solano et al., (2009).

\section{Antioxidant activities of Tilapia waste FPH}

\section{Diphenyl-1picrylhydrazyl radical scavenging activity}

The DPPH radical-scavenging assay has been widely used to investigate the scavenging activities of antioxidant compounds. DPPH is a stable free radical that shows maximum absorbance at $517 \mathrm{~nm}$ in ethanol. When DPPH encounters a proton-donating substance such as an antioxidant, the radical is scavenged and the absorbance is reduced (Shimada et al., 1992). The DPPH radical scavenging activity of $\mathrm{FPH}$ decreased with increasing concentration $(p<0.05)$. Results suggested that BHT showed highest radical scavenging activity of $80.31 \%$ at $200 \mathrm{mg} / \mathrm{L}$, whereas FPH showed highest of $77.40 \%$ at $100 \mathrm{mg} / \mathrm{L}$ (Table 2). The results were similar to Gajanan et al., $2016(65-80 \%$ at $15 \%$ DH FPH from threadfin bream wastes) and higher than the reports (64$79 \%$ DPPH free radical activity for different enzymes) of Elavarasan and Shamasundar (2013) in FPH from carps.

The radical scavenging activity of the FPH was studied at different concentrations and it was observed that with increase in concentration, the radical scavenging activities of FPH decreased. The present results are in agreement with the findings of Klompong et al., (2007) and Bougatef et al., (2010) on yellow stripe trevally hydrolysates and
Sardinella hydrolysates respectively where the DPPH radical scavenging activity was lower than that of BHA, BHT and $\alpha$-tocopherol which showed a DPPH radical scavenging activity in the range of $89-96 \%$ at $200 \mathrm{ppm}$ concentration. These antioxidants exhibited higher activity even at lower concentration but their use is strictly controlled due to their potential health issues (Bernardini et al., 2011).

\section{Ferric reducing antioxidant power of FPH}

From the present study, it was observed that BHT had $1.57 \%$ Abs at $200 \mathrm{mg} / \mathrm{L}$ whereas, FPH showed highest ferric reducing power of 2.18 at $500 \mu \mathrm{g} / \mathrm{mL}$ (Table 2). Gajana et al., (2016) observed that Ferric reducing antioxidant power of $1 \% \mathrm{FPH}$ prepared from frame waste of threadfin bream has increased with increasing concentration $(p<0.05)$. The ferric reducing power has increased with increase in DH. In the present study results are similar to the findings of Elavarasan and Shamasundar (2013) in FPH prepared from washed mince of Indian major carps and FPH from striped catfish frame protein (Tanuja et al., 2012).

The FPH samples showed ability to reduce the ferric cyanide complex. The degree of hydrolysis, nature of substrate, concentration of the sample and type of enzyme influences the reducing power (Zhu et al., 2006; Klompong et al., 2007).

\section{Metal chelating activity of FPH}

In present study, the metal chelating activity of FPH at different concentrations is depicted in Table 2. The results of present study showed that, the FPH was less efficient than commercial metal chelator (EDTA). The maximum metal chelating activity of FPH was seen at $500 \mathrm{mg} / \mathrm{L}$ which was $49.27 \%$ whereas EDTA at $1.0 \mathrm{mM}$ showed that $77.06 \%$. 
Table.1 Proximate composition of tilapia fish waste and fish protein hydrolysate

\begin{tabular}{|l|c|c|c|}
\hline S. NO & Percentage & Tilapia fish waste & Fish protein hydrolysate \\
\hline $\mathbf{1}$ & Moisture & $66.29 \pm 0.2$ & $5.04 \pm 0.03$ \\
\hline $\mathbf{2}$ & Protein & $14.93 \pm 0.3$ & $82.19 \pm 0.02$ \\
\hline $\mathbf{3}$ & Fat & $4.51 \pm 0.3$ & $0.58 \pm 0.02$ \\
\hline $\mathbf{4}$ & Ash & $8.6 \pm 0.04$ & $11.06 \pm 0.02$ \\
\hline
\end{tabular}

Table.2 Antioxidant activities of tilapia waste FPH

\begin{tabular}{l}
$\begin{array}{l}\text { Sample } \\
\text { concentrati } \\
\text { on }(\mathrm{mg} / \mathrm{l})\end{array}$ \\
\hline 100 \\
\hline 200 \\
\hline 300 \\
\hline 400 \\
\hline 500 \\
\hline BHT \\
EDTA
\end{tabular}

\begin{tabular}{|l|l|l|l|l|l|l|l|l|l|l|l|l|}
\hline \multicolumn{3}{|c|}{ DPPH Radical scavenging Activity (\%) } & \multicolumn{3}{|c|}{ Ferric Reducing Antioxidant Power } & \multicolumn{3}{|c}{ Metal Chelating Activity $(\%)$} \\
\hline R1 & R2 & R3 & Mean \pm SD & R1 & R2 & R3 & Mean \pm SD & R1 & R2 & R3 & Mean \pm SD \\
\hline 76.52 & 78.26 & 77.39 & $77.40 \pm 0.86$ & 0.70 & 0.62 & 0.65 & $0.65 \pm 0.05$ & 25.08 & 23.28 & 21.93 & $23.43 \pm 1.58$ \\
\hline 73.91 & 73.04 & 74.78 & $73.9 \pm 0.87$ & 0.86 & 0.95 & 0.92 & $0.91 \pm 0.04$ & 31.14 & 31.20 & 30.54 & $30.96 \pm 0.36$ \\
\hline 70.43 & 68.69 & 69.56 & $69.56 \pm 0.87$ & 1.37 & 1.45 & 1.37 & $1.38 \pm 0.09$ & 39.62 & 38.83 & 39.78 & $39.41 \pm 0.50$ \\
\hline 67.82 & 67.86 & 68.69 & $68.12 \pm 0.49$ & 1.84 & 1.72 & 1.84 & $1.80 \pm 0.08$ & 44.20 & 45.34 & 45.87 & $45.13 \pm 0.85$ \\
\hline 65.21 & 63.47 & 65.21 & $64.25 \pm 0.88$ & 2.13 & 2.28 & 2.13 & $2.18 \pm 0.10$ & 48.98 & 49.25 & 49.59 & $49.27 \pm 0.30$ \\
\hline 80.0 & 80.86 & 79.13 & $80.31 \pm 0.48$ & 1.53 & 1.52 & 1.53 & $1.57 \pm 0.06$ & 76.07 & 77.03 & 78.08 & $77.06 \pm 1.00$ \\
\hline & & & & & & & & & & & \\
\hline
\end{tabular}

Table.3 Antioxidant activities of tilapia waste FPH

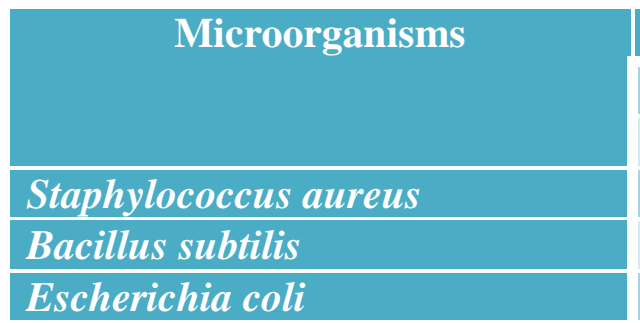

\begin{tabular}{|c|c|c|}
\hline \multicolumn{3}{|c|}{ Zone of inhibition in $\mathrm{mm}^{*}$} \\
\hline FPH & Ampicillin \\
\hline $14.83 \pm 0.76$ & $10.50 \pm 0.50$ & $20.83 \pm 0.76$ \\
\hline $12.83 \pm 1.04$ & $8.50 \pm 0.50$ & $21.50 \pm 1.50$ \\
\hline $11.17 \pm 1.04$ & $7.83 \pm 0.29$ & $20.50 \pm 0.50$ \\
\hline
\end{tabular}

The metal chelating ability of the FPH was very less at lower concentrations but increased with increasing the concentration. The chelating activity of peptides in hydrolysate could decrease lipid oxidation. The results are comparable with the result of Yarnpakdee et al., (2014) where the metal chelating activity was $53.8 \%$ at $30 \%$ degree of hydrolysis with papain enzyme. Samaranayaka and Li-Chan (2011) reported a chelating ability ranging from approximately $7 \%$ to $46 \%$ for hydrolysates derived from pacific hake muscle by different hydrolysis procedures, at $5 \mathrm{mg} / \mathrm{ml}$ assay concentration. Similarly, Thiansilakul et al., (2007) found a chelating activity of $60 \%$ in round scad protein muscle hydrolysate, although the assay concentration was not specified. However, its metal chelating ability was significantly lower than that of EDTA which has strongest metal chelating ability of $90 \%$ at $3 \mathrm{mg} / \mathrm{mL}$.

\section{Antimicrobial activity of FPH}

Antimicrobial activity of FPH sample against gram+ve bacteria such as Staphylococcus aureus, Bacillus subtilis and gram - ve such as Escherichia coli was assessed. The FPH showed inhibitory zone against Staphylococcus aureus, Bacillus subtilis and Escherichia coli. The activity of FPH was 
seen at 8 and $10 \mathrm{mg} / \mathrm{ml}$ with ampicillin as positive control at concentration of 1.0 $\mathrm{mg} / \mathrm{mL}$. In the present study, with increase in the concentration of FPH, the zone of inhibition also increased. The zone of inhibition for Staphylococcus aureus was $14.83 \pm 0.76$ at $1000 \mathrm{ppm}$ and $10.50 \pm 0.50$ at $800 \mathrm{ppm}$, for Bacillus subtilis it was $12.83 \pm 1.04$ at $1000 \mathrm{ppm}$ and $8.50 \pm 0.50$ at 800ppm, for Escherichia coli it was $11.17 \pm 1.04$ at $1000 \mathrm{ppm}$ and $7.83 \pm 0.29$ at 800ppm (Table 3). Our results are in comparison with Hayes et al., (2006) in which the antimicrobial effect of a protein hydrolysate increased in accordance with the diameter of the zone of inhibition formed. Similar results were reported by Khairi (2010) for FPH samples from viscera obtained using flavourzyme against $S$. aureus. Antimicrobial activity of hydrolysate with bromine samples could be attributed to the presence of antimicrobial peptides of cationic nature in the FPH samples. These peptides possess a net positive charge due to positively charged amino acid groups like lysine and arginine (Brogden et al., 2003). The other FPH samples did not show antimicrobial activity against test organisms. Similar results were obtained by Amissah (2012) for salmon skin FPH obtained using papain, trypsin and $\alpha$ chymotrypsin where no inhibitory effect was recorded towards E.coli K12 and Bacillus cereus. The reason for no inhibitory effect against microbes could be attributed to the fact that there are either no peptide sequences with inhibitory effect towards the selected microbes like B. subtilis, S. aureus and $V$. cholera - or the concentration of the crude hydrolysates used was too low to show any effect. But in the present study, at higher concentrations (800 and 1000ppm) the effect of E. coli and Bacillus was observed. The probable reason may be due to the fact that Gram negative bacteria are more resistant to antibacterial compounds such as lysozyme and penicillin than Gram positive bacteria due to the difference in the structure of their cell wall (Lehner et al., 2005). Gram-negative bacteria have more complex cell walls than Gram-positive bacteria due to the presence of two lipid membranes and lipopolysaccharides on the outer surface of the outer membrane (Lauth et al., 2002).

The fish protein hydrolysate prepared from tilapia wastes has exhibited a varied antioxidant and antimicrobial properties. The DPPH radical scavenging activity and metal chelating activity showed concentration dependent activity. FPH showed ferric reducing activity at all concentrations and exhibited highest reducing power of $2.18 \%$ at $500 \mu \mathrm{g} / \mathrm{mL}$. The hydrolysate sample prepared using papain enzyme inhibited the growth of Staphylococcus aureaus, Bacillus subtilis and $E$. coli indicating antimicrobial activity. Hence it is feasible to produce antioxidants and antimicrobial peptides from tilapia waste by enzymatic hydrolysis and utilise them as antioxidant and antimicrobial compounds.

\section{Acknowledgement}

The authors would like to thank the Vice Chancellor of Sri Venkateswara Veterinary University (SVVU), Tirupati; the Dean of Fishery Science, SVVU, Tirupati and the Associate Dean, College of Fishery science, SVVU, Muthukur for providing facility and support.

\section{References}

Amissah, J. (2012). Bioactive properties of salmon skin protein hydrolysates. M.Sc. thesis, Mcgill University, Montreal, Quebec, Canada.

Amiza, M.A., Nurul Ashikin, S. and Faazaz, A.L. (2011). Optimization of Enzymatic Protein Hydrolysis from Silver Catfish (Pangasius sp.) Frame and Biological Characteristics of Protein Hydrolysates 
from Fermented Shrimp by-Products. Food Chemistry 112, 671-675.

Arnesen, J. A. and Gildberg, A. (2006). Extraction of muscle proteins and gelatine from cod head. Process Biochemistry, 41(3), 697-700.

Batista, I., Ramos, C., Coutinho, J., Bandarra, N. M. and Nunes, M. L., 2010. Characterization of protein hydrolysates and lipids obtained from black scabbardfish (Aphanopus carbo) byproducts and antioxidative activity of the hydrolysates produced. Process Biochemistry, 45(1):18-24.

Bauer, A.W., Kirby, W.M.M. and Sherris, J.C., 1966.Antibiotic susceptibility testing by a standardized single disk method. American Journal of Clinical Pathology, 45: 493-496.

Benjakul, S. and Morrissey, M. T., 1997.Protein hydrolysates from Pacific whiting solid wastes. Journal of Agricultural and Food Chemistry, 45(9):3423-3430.

Bernardini, R., Harnedy, P., Bolton, D., Kerry, J., O’Neill, E., Mullen, A. M. and Hayes, M. (2011).Antioxidant and antimicrobial peptidichydrolysates from muscle protein sources and by-products. Food Chemistry, 124(4): 1296-1307.

Bhaskar, N., Benila, T., Radha, C. and Lalitha, R. G. (2008). Optimization of enzymatic hydrolysis of visceral waste proteins of Catla (Catlacatla) for preparing protein hydrolysate using a commercial protease. Bioresource Technology, 99(2):335-343.

Bougatef, A., Nedjar-Arroume, N., Manni, L., Ravallec, R., Barkia, A., Guillochon, D. and Nasri, M. (2010). Purification and identification of novel antioxidant peptides from enzymatic hydrolysates of sardinelle (Sardinella aurita) byproducts proteins. Food chemistry, 118(3): 559-565.
Boyer, R.F. and Mccleary, C.J. (1987). Superoxide ion as a primary reductant in ascorbate-mediated ferritin iron release. Free Radical Biology and Medicine, 3:389-395.

Bueno-Solano, C., Lopez- Cervantes, J., Campas-Baypoli, O.N., LauterioGarcia, R.,Adan-Bante, N.P. and Sanchez-Machado, D.I. (2009).Chemical and Biological characteristics of protein hydrolysates from fermented shrimp by products.Food Chemistry, 112:671-675.

Chalamaiah, M., NarsingRao, G., Rao, D. G. and Jyothirmayi, T. (2010).Protein hydrolysates from meriga (Cirrhinusmrigala) egg and evaluation of their functional properties.Food Chemistry, 120:652-657.

Elavarasan, K. and Shamasundar, B.A. (2014). Angiotensin I-converting enzyme inhibitory activity of protein hydrolysates prepared from three freshwater carps (Catlacatla, Labeorohita and Cirrhinusmrigala) using flavorzyme. International Journal of Food Science and Technology, 49:1344-1350.

Foh, M.B.K., Kamara, M.T., Amadou, I., Foh, B.M. and WenshuI, X. (2011). Chemical and physicochemical properties of Tilapia (Oreochromis niloticus) fish protein hydrolysates and concentrate. International Journal of Biological Chemistry, 5:21-36.

Gajanan, P.G., Elavarasan, K., and Shamasundar, B. A. (2016). Bioactive and functional properties of protein hydrolysates from fish frame processing waste using plant proteases. Environmental Science and Pollution Research, 23(24):24901-24911.

Hayes, M., Ross, R. P., Fitzgerald, G. F., Hill, C. and Stanton, C. (2006). Caseinderived antimicrobial peptides generated by Lactobacillus acidophilus 
DPC6026. Applied and Environmental Microbiology, 72(3):2260-2264.

Hou, H., Li, B., Zhao, X., Zhang, Z.H. and Li, P.L. (2011). Optimization of Enzymatic Hydrolysis of Alaska Pollock Frame for Preparing Protein hydrolysate. Food Research International, 38:45-50.

Ito, N., Hirose, M., Fukushima, S., Tsuda, H., Shirai, T. and Tatematsu, M. (1986). Studies on antioxidants: Their carcinogenic and modifying effects on chemical carcinogenic. Food and Chemical Toxicology, 24: 1099-1102.

Je, J. Y., Qian, Z. J., Byun, H. G. and Kim, S. K. (2007). Purification and characterization of an antioxidant peptide obtained from tuna backbone protein by enzymatic hydrolysis. Process Biochemistry, 42(5):840-846.

Khairi, Z. (2010). Functional and bioactive components from mackerel (Scomberscombrus) and blue whiting (Micromesistiuspoutassou) processing waste. $\mathrm{PhD}$ thesis, Dublin Institute of Technology, Ireland.

Klompong, V., Benjakul, S., Kantachote, D. and Shahidi, F. (2007). Antioxidative activity and functional properties of protein hydrolysate of yellow stripe trevally (Selaroidesleptolepis) as influenced by the degree of hydrolysis and enzyme type. Food chemistry, 102(4):1317-1327.

Lanier, T. C. (1992). Measurement of surimi composition and functional properties. Surimi Technology. (Eds., TC Lanier and CM Lee) Macrel Decker, Inc., New York. USA, 3441:1123-1163.

Lauth, X., Shike, H., Burns, J.C., Westerman, M.E., Ostland, V.E., Carlberg, J.C., Van Oslt, Nizet, V., Tylor, S.W., and Shimizu, C. and Bulet., H. (2002). Discovery and characterization of two isoforms of moronecidin, a novel antimicrobial peptide from hybrid striped bass. Journal of Biological chemistry, 277(7):5030-5039.

Lin, C.C. and Liang, J.H. (2002). Effect of antioxidants on the oxidative stability of chicken breast meat in a dispersion system. Journal of Food Science, 67(2):530-533.

Miraliakbari, H. and Shahidi, F. (2008). Antioxidant activity of minor components of tree nut oils. Food Chemistry, 111(2):421-427.

Ovissipour, M., Taghiof, M., Motamedzadegan, A., Rasco, B. and Molla, A. E. (2009). Optimization of enzymatic hydrolysis of visceral waste proteins of beluga sturgeon Husohuso using Alcalase. International Aquatic Research, 1(1):31-38.

Oyaizu, M. (1986). Studies on product browning reaction: antioxidant activity of products of browning reaction prepared from glucosamine. Journal of Nutrition, 44:307-315.

Rajanbabu, V.C.J. (2011). Applications of antimicrobial peptides from fish and perspectivesfor future. Peptides, 32: 415-20.

Ren, J., Zhao, M., Shi, J., Wang, J., Jiang, Y., Cui, C. and Xue, S. J. (2008). Purification and identification of antioxidant peptides from grass carp muscle hydrolysates by consecutive chromatography and electrospray ionization-mass spectrometry. Food Chemistry, 108(2):727-736.

Samaranayaka, A. G. and Li-Chan, E. C. (2011). Food-derived peptidic antioxidants: A review of their production, assessment, and potential applications. Journal of Functional Foods, 3(4):229-254.

See, S. F., Hoo, L. L. and Babji, A. S. (2011). Optimization of enzymatic hydrolysis of Salmon (Salmosalar) skin by Alcalase. International Food Research Journal, 18(4):1359-1365. 
Shahidi, F., and Zhong, Y. (2008). Bioactive peptides. Journal of AOAC International, 91(4):914-931.

Shimada, K., Fujikawa, K., Yahara, K. and Nakamura, T. (1992).Antioxidative properties of xanthan on the autoxidation of soybean oil in cyclodextrin emulsion. Journal of Agricultural and Food Chemistry, 40(6):945-948.

Souissi, N., Bougatef, A., Triki-Ellouz, Y. and Nasri, M. (2007). Biochemical and functional properties of sardinella (Sardinella aurita) by-product hydrolysates. Food Technology and Biotechnology, 45(2), 187-194.

SPSS, I. Statistics (2010). SSS Inc., IBM Company@, Version, 20.

$\mathrm{Su}, \mathrm{Y}$. (2011). Isolation and identification of pelteobagrin, a novel antimicrobial peptide from the skin mucus of yellow catfish (Pelteobagrus fulvidraco). Comparative Biochemistry and Physiology Part B: Biochemistry and Molecular Biology, 158(2): 149-154.

Tanuja, S., Viji, P., Zynudheen, A. A. and Joshy, C. (2012). Composition, functional properties and antioxidative activity of hydrolysates prepared from the frame meat of Striped catfish (Pangasianodon hypophthalmus). Egyptian Journal of Biology, 14(1), $27-$ 35.
Thiansilakul, Y., Benjakul, S. and Shahidi, F. (2007). Compositions, functional properties and antioxidative activity of protein hydrolysates prepared from round scad (Decapterusmaruadsi). Food Chemistry, 103(4), 1385-1394.

Yarnpakdee, S., Benjakul, S., Kristinsson, H. G., and Kishimura, H. (2015). Antioxidant and sensory properties of protein hydrolysate derived from Nile tilapia (Oreochromis niloticus) by oneand two-step hydrolysis. Journal of food science and technology, 52(6):33363349.

Yen, G. C., and Wu, J. Y. (1999).Antioxidant and radical scavenging properties of extracts from Ganodermatsugae. Food Chemistry, 65(3): 375-379.

Zhang, Y. X., Zou, A. H., Manchu, R. G., Zhou, Y. C., and Wang, S. F. (2008).Purification and antimicrobial activity of antimicrobial protein from brown-spotted grouper, Epinephelusfario. Zoological Research, 29(6):627-632.

Zhu, K., Zhou, H. and Qian, H. (2006). Antioxidant and free radical-scavenging activities of wheat germ protein hydrolysates (WGPH) prepared with alcalase. Process Biochemistry, 41(6):1296-1302.

\section{How to cite this article:}

Srikanya, A., K. Dhanapal, K. Sravani, K. Madhavi, B. Yeshdas and Praveen Kumar, G. 2018. Antioxidant and Antimicrobial Activity of Protein Hydrolysate Prepared from Tilapia Fish Waste by Enzymatic Treatment. Int.J.Curr.Microbiol.App.Sci. 7(10): 2891-2899. doi: https://doi.org/10.20546/ijcmas.2018.710.336 